\title{
Comparative molecular analysis of Herbaspirillum strains by RAPD, RFLP, and 16S rDNA sequencing
}

\author{
Juliana R.L. Soares-Ramos, Humberto J.O. Ramos, Leonardo M. Cruz, Leda S. Chubatsu, \\ Fábio O. Pedrosa, Liu U. Rigo and Emanuel M. Souza \\ Universidade Federal do Paraná, Departamento de Bioquímica e Biologia Molecular, Curitiba, PR, Brazil.
}

\begin{abstract}
Herbaspirillum spp. are endophytic diazotrophic bacteria associated with important agricultural crops. In this work, we analyzed six strains of $H$. seropedicae (Z78, M2, ZA69, ZA95, Z152, and Z67) and one strain of $H$. rubrisubalbicans (M4) by restriction fragment length polymorphism (RFLP) using Hindlll or Dral restriction endonucleases, random amplified polymorphic DNA (RAPD), and partial sequencing of 16S rDNA. The results of these analyses ascribed the strains studied to three distinct groups: group I, consisting of M2 and M4; group II, of ZA69; and group III, of ZA95, Z78, Z67, and Z152. RAPD fingerprinting showed a higher variability than the other methods, and each strain had a unique electrophoretic pattern with five of the six primers used. Interestingly, $H$. seropedicae M2 was found by all analyses to be genetically very close to $H$. rubrisubalbicans $\mathrm{M} 4$. Our results show that RAPD can distinguish between all Herbaspirillum strains tested.
\end{abstract}

Key words: Herbaspirillum, RAPD, RFLP, Phylogeny, 16S rDNA.

Received: December 9, 2002; Accepted: August 10, 2003.

\section{Introduction}

Herbaspirillum spp. are a group of $\beta$-Proteobacteria (Baldani et al., 1986; Gillis et al., 1990) comprising three species: H. seropedicae (Baldani et al., 1986), $H$. rubrisubalbicans (Baldani et al., 1996) and $H$. frisingense (Kirchhof et al., 2001). These bacteria are endophytic diazotrophs capable of colonizing plant tissues of gramineae such as rice, maize, sugar cane, sorghum, banana, and pineapple (Olivares et al., 1993; Baldani et al., 1986, 1992; Cruz et al., 2001). Inoculation with Herbaspirillum spp. can improve plant growth and productivity (Baldani et al., 1995). These effects are attributed in part to the nitrogen fixed by the bacteria (Döbereiner and Pedrosa, 1987; Döbereiner 1991; Döbereiner et al., 1995; Boddey et al., 1995; Olivares et al., 1996) and also to the production of phytohormones, such as auxins and gibberillins, which can induce plant growth (Bastián et al., 1998). However, evaluation of the bacterial contribution to the associated plant under field conditions is complicated by the presence, in both soil and seeds, of other bacteria which can associate with the crop (Barraquio et al., 1997). The recovery and identification of inoculated strains is es-

Send correspondence to Emanuel M. Souza. Universidade Federal do Paraná, Departamento de Bioquímica e Biologia Molecular, Caixa Postal 19046, 81531-990 Curitiba, PR, Brazil. E-mail: souzaem@ bio.ufpr.br. sential to correlate gains in productivity with successful colonization.

In recent years, much progress has been made in the development of molecular tools to identify bacteria, such as restriction fragment length polymorphism (RFLP), 16S ribosomal DNA (rDNA) sequencing, and random amplified polymorphic DNA (RAPD).

In this work, we analyzed six strains of Herbaspirillum seropedicae (Z78, M2, ZA69, ZA95, Z152 and Z67) and one strain of Herbaspirillum rubrisubalbicans (M4) by a combination of methods for genetic differentiation, including RFLP, RAPD, and comparison of partial sequences of the $16 \mathrm{~S}$ rRNA genes.

\section{Materials and Methods}

\section{Strains and culture conditions}

The Herbaspirillum seropedicae strains M2, ZA69, ZA95, Z152, Z78 and Z67, and the H. rubrisubalbicans strain M4 used in this study were grown overnight in $50 \mathrm{~mL}$ NFbHP-malate (Klassen et al., 1997) at $30^{\circ} \mathrm{C}$ in a rotary shaker.

\section{RAPD fingerprinting}

Genomic DNA of Herbaspirillum strains was purified as follows: $5 \mathrm{~mL}$ of the overnight cultures were centrifuged, and the pellet was suspended in $500 \mu \mathrm{L}$ TES buffer 
$(50 \mathrm{mmol} / \mathrm{L}$ Tris-HCL, $20 \mathrm{mmol} / \mathrm{L} \quad$ EDTA, and $100 \mathrm{mmol} / \mathrm{L} \mathrm{NaCl}, \mathrm{pH} 8.0$ ), treated with $100 \mu \mathrm{g}$ of lysozyme, and incubated at $30{ }^{\circ} \mathrm{C}$ for $3 \mathrm{~h}$. Cells lysis was completed by adding $50 \mu \mathrm{L}$ SDS (10\%), followed by incubation at room temperature for $5 \mathrm{~min}$ and treatment with proteinase $\mathrm{K}(100 \mu \mathrm{g} / \mathrm{mL})$ at $37{ }^{\circ} \mathrm{C}$ overnight. Purified DNA was obtained by three successive extractions with equilibrated phenol (1 vol) and one with chloroform: isoamyl alcohol (24:1). The genomic DNA was precipitated with 2 volumes of absolute ethanol, washed with $70 \%$ ethanol, vacuum-dried, and suspended in $200 \mu \mathrm{L}$ of $\mathrm{T}_{10} \mathrm{E}_{1}$ (10 mM Tris, 1 mM EDTA, pH 8.0).

Ten ng of genomic Herbaspirillum DNA were submitted to random amplification using the Ready $\mathrm{To}^{\mathrm{G}}{ }^{\mathrm{TM}}$ RAPD Analysis Beads Kit (Amersham Biosciences) according to the manufacturer's instructions. Six different primers, previously described for characterization of bacterial strains (Amersham Biosciences), were used in the RAPD reactions (Table 1). The electrophoretic profiles were scored according to the presence (1) or absence (0) of a particular band, generating a binary matrix. Similarity of all pair-wise combinations of the numerical profiles was determined by Dice's coefficient (Dice, 1945) and clustered by unweighted pair-group analysis using arithmetical averages (UPGMA) (Sokal and Michener, 1958). A dendrogram was constructed from the patterns, using the NTSYS pc 2.0 program (Exeter Software - scientific software for teaching and research - http://www. exetersoftware.com/index.html). All samples and a negative control without DNA were run in parallel in the same thermocycler. At least three independently amplified fragment patterns of each sample were obtained to confirm the result.

\section{RFLP fingerprinting}

Genomic DNA isolated as described above was digested with HindIII or DraI (Invitrogen) and submitted to agarose gel $(0.7 \%)$ electrophoresis. Analyses were performed as described for RAPD fingerprinting.

\section{DNA sequencing of $16 S$ rDNA}

The 16S rDNA of the Herbaspirillum strains was amplified using primers $\mathrm{Y} 1$ and $\mathrm{Y} 3$ as previously described (Cruz et al., 2001). Briefly, diluted overnight cultures (1:10) were boiled for $10 \mathrm{~min}$ and cooled on ice. Reaction mixtures $(25 \mu \mathrm{L})$ contained $10 \mu \mathrm{L}$ of boiled cultures, Taq DNA polymerase buffer $(50 \mathrm{mmol} / \mathrm{L} \mathrm{KCl}, 1.5 \mathrm{mmol} / \mathrm{L}$ $\mathrm{MgCl}_{2}, 10 \mathrm{mmol} / \mathrm{L}$ Tris-HCl, $\left.\mathrm{pH} 9.0\right), 200 \mu \mathrm{mol} / \mathrm{L}$ of each deoxynucleotide, $0.4 \mu \mathrm{mol} / \mathrm{L}$ of each primer, and $1 \mathrm{U}$ of Taq DNA polymerase (Invitrogen). The mixtures were incubated at $93{ }^{\circ} \mathrm{C}$ for $2 \mathrm{~min}$, followed by 34 amplification cycles of $93{ }^{\circ} \mathrm{C}$ for $45 \mathrm{~s}, 62{ }^{\circ} \mathrm{C}$ for $30 \mathrm{~s}$, and $72{ }^{\circ} \mathrm{C}$ for $2 \mathrm{~min}$ each. Conserved regions of $16 \mathrm{~S}$ rDNA from subclasses alpha, beta and gamma of the Proteobacteria were identified from the alignment of 65 sequences from the GenBank database, and used to design the primers 16S362f, 16S786f, 16S1203f, 16S1110r, and 16S805r (Table 1). DNA sequences of the amplified products were determined using dye terminator chemistry in an ABI Prism 377 automated DNA sequencer (Applied Biosystems). The 16S rDNA sequences obtained were deposited in the GenBank database, and their accession numbers are in parentheses: $H$. seropedicae strains M2 (AY191276), ZA69 (AY191272), ZA95 (AY191274), Z152 (AY191273), Z78 (AY191275).

\section{DNA Sequencing analysis}

DNA sequences were assembled and edited using the BioEdit package (Hall, 1999) and aligned by the Contig As-

Table 1 - Sequences of the primers used.

\begin{tabular}{lll}
\hline Primers & Sequence $\left(5^{\prime} \rightarrow 3^{\prime}\right)$ & Reference \\
\hline Y1 & TGGCTCAGAACGAACGCTGGCGGC & Young et al., 1991 \\
Y2 & ACTCCTACGGGAGGCAGCAGTGGG & Young et al., 1991 \\
Y3 & CTGACCCCACTTCAGCTTGTTCCAT & Cruz et al., 2001 \\
16S362f & CTCCTACGGGAGGCAGTGGGG & this work \\
16S786f & CGAAAGCGTGGGGAGCAAACAGG & this work \\
16S1203f & GAGGTGGGGATGACGTCAAGTCCTC & this work \\
16S1110r & TGCGCTCGTTGCGGGACTTAACC & this work \\
16S805r & GACTACCAGGGTATCTAATCCTG & this work \\
RAPD Primer 1 & GGTGCGGGAA & Amersham Biosciences \\
RAPD Primer 2 & GTTTCGCTCC & Amersham Biosciences \\
RAPD Primer 3 & GTAGACCCGT & Amersham Biosciences \\
RAPD Primer 4 & AAGAGCCCGT & Akopyanz et al., 1992 \\
RAPD Primer 5 & AACGCGCAAC & Akopyanz et al., 1993 \\
RAPD Primer 6 & CCCGTCAGCA & Akopyanz et al., 1994 \\
\hline
\end{tabular}


sembly Program (CAP) (Huang, 1992). The phylogenetic tree was obtained by a neighbor-joining method, using the MEGA 2 software (Kumar et al., 2001).

\section{Results and Discussion}

The total DNA restriction patterns of the Herbaspirillum strains were used to construct a dendrogram (Figure 1A), which clustered them into three groups (Figure 1A and Table 2). The HindIII or DraI restriction profiles of M2 and M4 were identical, as were those of $H$. seropedicae Z67 and Z78, thus defining two electrophoretic types. Strains ZA95 and Z152 had identical patterns with DraI, but HindIII produced two different bands. However, analyses of their electrophoretic profiles positioned these strains together with Z67 and Z78, forming a cluster with a similarity coefficient of $100 \%$. $H$. seropedicae ZA69 had a distinct electrophoretic pattern and was allocated into a separate group, closer to the M2/M4 cluster. These results indicate that, as far as the separation of the Herbaspirillum strains is concerned, restriction length polymorphism has a limited potential.

Genomic diversity of the Herbaspirillum strains was also investigated by random amplified polymorphic DNA (RAPD) analysis. Each of the six primers used generated electrophoretic DNA patterns for the strains studied

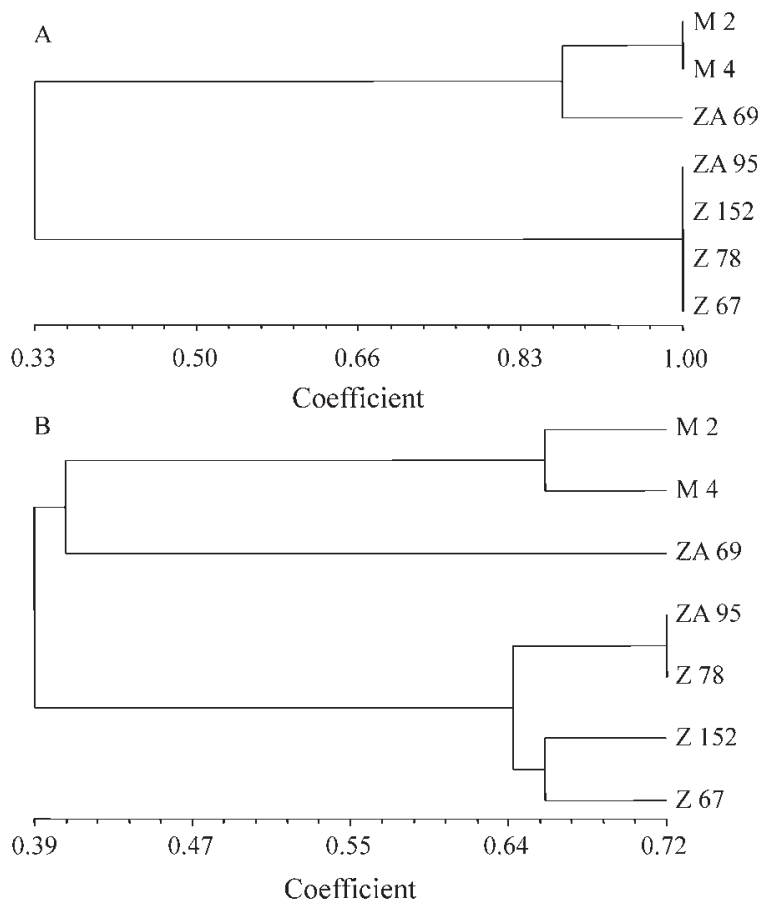

Figure 1 - Panel A - Dendrogram inferred from the RFLP profiles obtained by digestion of total DNA of Herbaspirillum strains with restriction endonucleases HindIII or DraI. Panel B - Dendrogram inferred from RAPD profiles of the Herbaspirillum strains. Similarities were calculated using Dice's coefficient, and clustering was achieved by UPGMA (Sokal and Michener, 1995).
Table 2 - Genotypic characterization of Herbaspirillum spp., as revealed by RAPD and RFLP profiling and 16S rDNA sequence analysis.

\begin{tabular}{lccc}
\hline Organism & RAPD pattern $^{a}$ & RFLP pattern $^{b}$ & 16S rDNA $^{c}$ \\
\hline H. seropedicae & & & \\
M2 & aaaaa & aa & a \\
ZA69 & cccccc & bb & b \\
ZA95 & dddddd & cc & c \\
Z152 & deeeee & cd & c \\
Z67 & efffff & ce & c \\
Z78 & fggggg & ce & c \\
H. rubrisubalbicans & & & \\
M4 & bbbbbb & aa & a \\
\hline
\end{tabular}

${ }^{a}$ RAPD patterns obtained with different primers. Each letter defines a common pattern for primers 1 to 6 , respectively (see Table 1 ).

${ }^{b}$ RFLP patterns obtained with restriction endonucleases HindIII and DraI, respectively. Each letter defines a common pattern.

${ }^{c}$ The Y1-Y3 region of the $16 \mathrm{~S}$ rDNA covers approximately $1500 \mathrm{bp}$. The letters represent genotypes in the same cluster.

(Table 2 and Figure 2). The analysis of these patterns produced highly congruent DNA fingerprint clustering, in overall agreement with the RFLP results (Figure 1A). With the exception of primer 1 , all primers produced unique patterns for M2 and M4, allowing unequivocal differentiation of these strains. As with RFLP, analysis of the RAPD fingerprinting patterns revealed three main clusters of strains (Figure 1B), with a similarity level of approximately $39 \%$. Cluster I was formed by M2 and M4, with a similarity level of $65 \%$. Strain ZA69 was located in a separate branch, closer to M2 and M4, but with a similarity level of $40 \%$. Strains ZA95, Z78, Z152, and Z67 were located in a separate cluster, occupying distinct positions in the dendrogram and forming two sub-groups, comprising strains ZA95 and Z78 (72\% similarity), and Z152 and Z67 (65\% similarity), respectively. Cluster analysis of RAPD profiles supported the differences noted by visual observation of the electrophoretic profiles (data not shown). Furthermore, the profiles obtained by RAPD showed a higher level of variability than those obtained by RFLP, since, using primers 2 to 6 , all strains could be distinguished by at least one band (Table 2). These results show that RAPD is the most sensitive and convenient method tested to unequivocally identify Herbaspirillum strains using whole genomic DNA. However, since low reproducibility has been attributed to RAPD profiling, this may reduce its potential application (Penner et al., 1993; Wang et al., 1993). To minimize this effect, we used the same procedure for DNA purification from all strains and a commercially available RAPD system with standardized components and conditions, which was reliable and reproducible in this study. The Ready-To-Go (Amersham Biosciences) beads format also significantly reduced the number of pipetting steps, thereby increasing the reproducibility of the RAPD technique. 


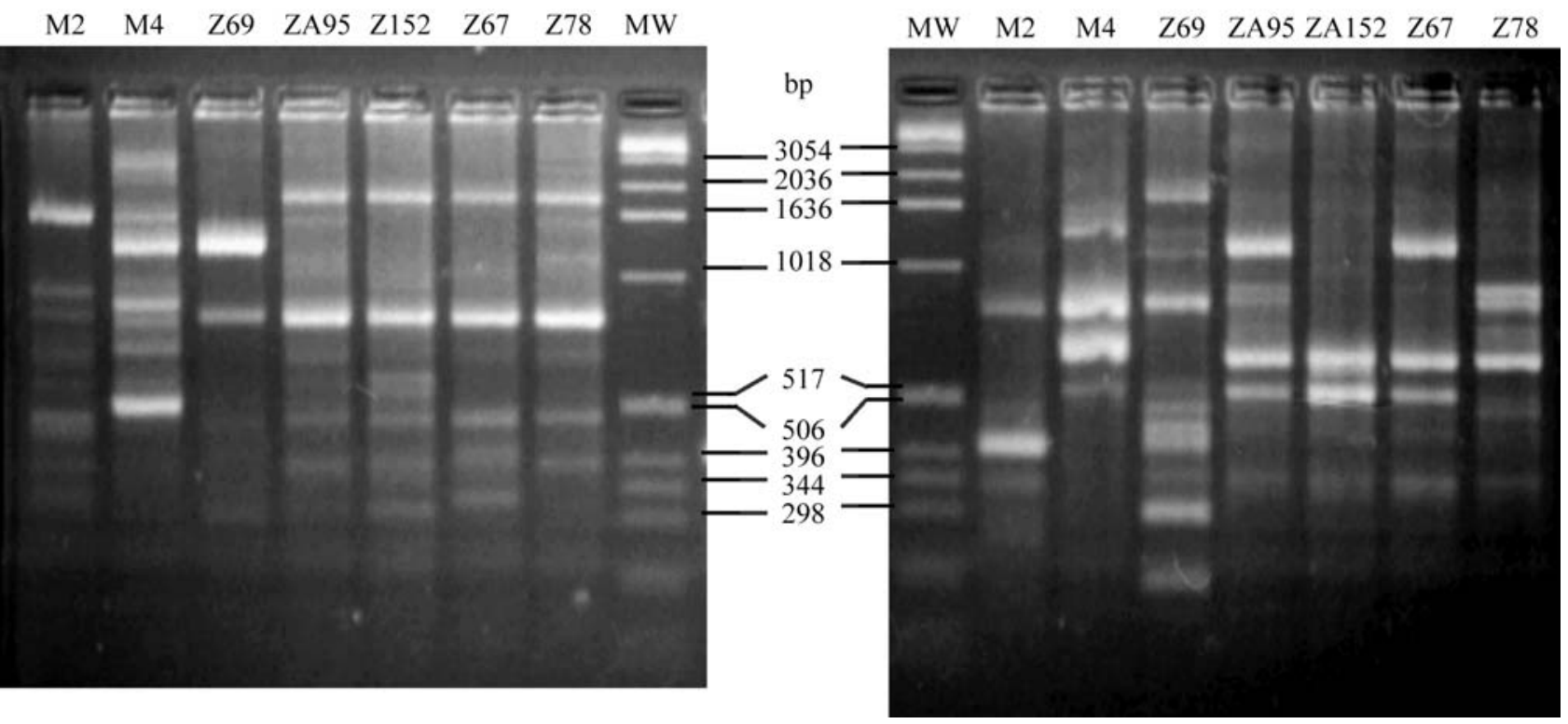

Figure 2 - Agarose gel (2.0\%) electrophoresis of RAPD profiles of the Herbaspirillum seropedicae (M2, Z69, ZA95, ZA152, Z67 and Z78) and Herbaspirillum rubrisubalbicans (M4) strains obtained with primers 3 (left) or 4 (right). MW indicates the molecular weight markers in bp (1 kb Ladder, Invitrogen). DNA was stained with ethidium bromide $(0.5 \mu \mathrm{g} / \mathrm{mL})$.

Lasker (2002) recently reported that repeated runs of the same or different DNA preparations of the same strain of Aspergillus fumigatus produced highly reproducible results using RFLP, RAPD, sequence-specific DNA primer (SSDP) analysis or polymorphic microsatellite markers (PMM) analysis (Lasker, 2002). Coenye et al. (2002) reached similar conclusions by analyzing Burkholderia cepacia Genomovar III isolates, using pulsed-field gel electrophoresis (PFGE), BOX-PCR fingerprinting and random amplified polymorphic DNA (RAPD) typing.

Zhang et al. (2002) comparing typing methods to differentiate Streptococci Group B showed that RAPD was a useful assay for the rapid characterization of these strains and was more discriminatory than conventional serological assays. These authors also reported that the RAPD assay was faster, more convenient and easier to perform than alternative DNA analytical procedures such as pulsed-field gel electrophoresis. In addition, van den Braak et al. (2002) obtained highly congruent DNA fingerprint clustering of vancomycin-resistant enterococci (VRE), employing well-standardized RAPD or PFGE protocols.

The 16S rDNA from all Herbaspirillum strains used in this work was amplified using primers Y1 (Young et al., 1991) and Y3 (Cruz et al., 2001), which allowed the amplification of the nearly complete $16 \mathrm{~S}$ rRNA genes. The PCR products were thoroughly sequenced in both orientations, yielding the complete sequence of the Y1-Y3 fragment with a three-times redundancy. The partial sequence of the $16 \mathrm{~S}$ rRNA gene of the $H$. seropedicae strain Z67, deposited in the GenBank database (Kirchhof et al., 2001), differed from the sequence obtained in this study by three bases. The 16S rDNA sequence of the H. rubrisubalbicans strain M4 deposited in GenBank (Kirchhof et al., 2001) was identical to that determined in this work.

Ribosomal operons are of great relevance for the study of bacterial evolution and phylogeny (Woese, 1987), and sequencing of $16 \mathrm{~S}$ rDNA has been widely used to re-construct phylogenetic relationships of microorganisms (Gutell et al., 1994; Luz et al., 1998).

Phylogenetic analysis of the partial $16 \mathrm{~S}$ rDNA sequences from the Herbaspirillum strains studied here, together with related sequences deposited in GenBank (Figure 3), positioned the Herbaspirillum species ( $H$. seropedicae, $H$. rubrisubalbicans and $H$. frisingensis), Herbapirillum-like isolates, and the related species Pseudomonas huttiensis in separate branches, well supported by the bootstrap values (see Figure 3). Within the $H$. seropedicae branch, strains Z67, Z78, ZA95, and Z152 formed a tight cluster with a bootstrap value of 96 . Strain ZA69 formed a separate cluster in the same branch, consistent with its taxonomic position. Strains $H$. seropedicae M2 and $H$. rubrisubalbicans $\mathrm{M} 4$ had very similar $16 \mathrm{~S}$ rDNA sequences, and grouped in the $H$. rubrisubalbicans branch with a bootstrap value of 89. Although strains M2 and M4 belong to different species, as determined by physiological assays (Baldani et al., 1996), the analyses carried out in this work showed very close genetic proximity.

The genetic proximity between strains of the species $H$. seropedicae and H rubrisubalbicans was also observed by Cruz et al. (2001), using ARDRA (amplified rDNA restriction analysis) and sequencing of approximately $300 \mathrm{pb}$ of the $16 \mathrm{~S} \mathrm{rDNA}$, thereby highlighting the low level of variability of these organisms. Kirchhof et al. (2001) and Caballero-Mellado and Martinez-Romero (1994) evaluating 


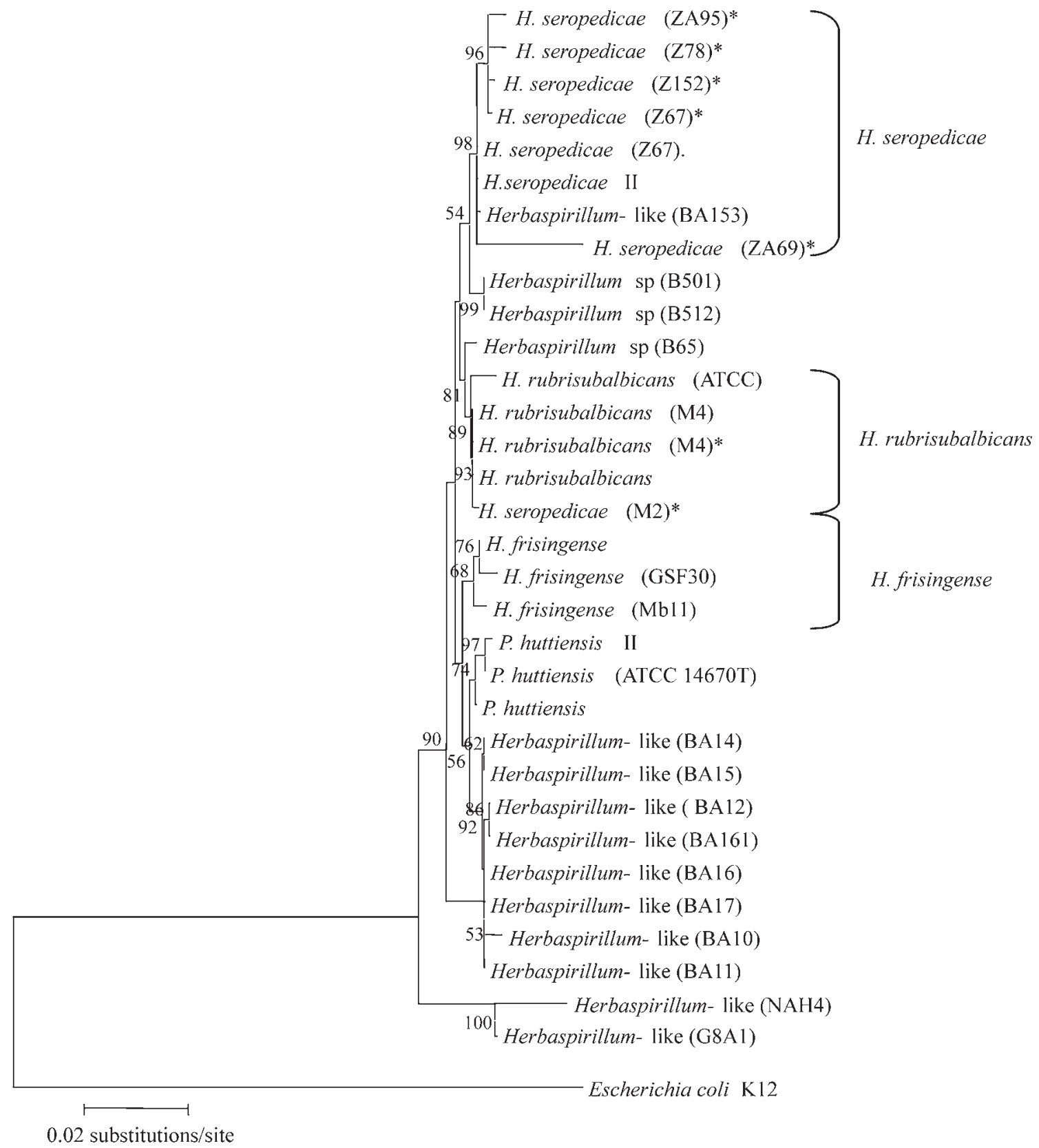

Figure 3 - Phylogenetic tree inferred from 16S rDNA sequences of Herbaspirillum strains obtained in this work (*) or available in the GenBank database, and representative beta-Proteobacteria. The tree was constructed by the neighbor-joining method. The boot-strap values were calculated from 2000 trees, and each number on a branch indicates the percentage of trees in which the node was supported. The bar represents the percentage of sequence divergence.

Herbaspirillum frisingense and Gluconacetobacter diazotrophicus strains, also concluded that Herbaspirillum strains formed a group of tight genetic relationships and low variability.

Herbaspirillum spp. are endophytic diazotrophs with low survival in plant-free soils (Baldani et al., 1992), suggesting a strong adaptation of these bacteria to the endophytic state. McArthur et al. (1988) suggested that close genetic proximity may be accounted for by adaptation to very stable habitats for long periods.
In summary, molecular tools evaluating either the $16 \mathrm{~S}$ rRNA gene or the entire genome (RAPD and RFLP) allowed distinction of the seven Herbaspirillum strains studied. RAPD profiling using a commercially available system unequivocally differentiated all the strains tested and proved very reliable. This finding agrees with the observation that the $16 \mathrm{~S}$ rDNA sequences are highly conserved among the species and potentially useful to distinguish between distantly related organisms (Woese, 1987). In contrast, RAPD utilizes fragment amplification of the whole 
genome, therefore being well suited to detect differences between closely related organisms.

\section{Acknowledgments}

We thank Roseli Prado, Valter Baura and Julieta Pie for technical assistance. CNPq/PRONEX/Fundação Araucária/Paraná Tecnologia supported this work.

\section{References}

Baldani JI, Baldani VLD, Seldin L and Döbereiner J (1986) Characterization of Herbaspirillum seropedicae gen. nov., sp. nov., a root-associated nitrogen fixing bacterium. Int J Syst Bacteriol 36:86-93.

Baldani VLD, Baldani JI, Olivares F and Döbereiner J (1992) Identification and ecology of Herbaspirillum seropedicae and the closely related Pseudomonas rubrisubalbicans. Symbiosis 13:65-73.

Baldani VLD, Olivares FL and Döbereiner J (1995) Selection of Herbaspirillum spp. strains associated with rice seedlings amended with ${ }^{15} \mathrm{~N}$-labeled fertilizer. 202. International Symposium on Sustainable Agriculture for the tropics - The role of Biological Nitrogen Fixation, Angra dos Reis, Brazil.

Baldani JI, Pot B, Kirchhof G, Falsen E, Baldani VLD, Olivares FL, Hoste B, Kersters K, Hartmann A, Gillis M and Döbereiner J (1996) Emended description of Herbaspirillum; inclusion of [Pseudomonas] rubrisubalbicans, a mild plant pathogen, as Herbaspirillum rubrisubalbicans comb. nov.; and classification of clinical isolates (EF group 1) as Herbaspirillum species 3. Int J Syst Bacteriol 46:802-810.

Barraquio WL, Revilla L and Ladha JK (1997) Isolation of endophytic diazotrophic bacteria from wetland rice. Plant Soil 194:15-24.

Bastián F, Cohen A, Piccoli P, Luna V, Baraldi R and Bottini R (1998) Production of indole-3-acetic acid and gibberellins A1 and A3 by Acetobacter diazotrophicus and Herbaspirillum seropedicae in chemically-defined culture media. Plant Growth Regul 24:7-11.

Boddey RM, de Oliveira OC, Urquiaga S, Reis VM, Olivares FL, Baldani VLD and Döbereiner, J (1995) Biological nitrogen fixation associated with sugar cane and rice: contributions and prospects for improvement. Plant Soil 174:195-209.

Caballero-Mellado J and Martinez-Romero E (1994) Limited genetic diversity in the endophytic sugarcane bacterium Acetobacter diazotrophicus. Appl Environ Microbiol 60:1532-1537.

Coenye T, Spilker T, Martin A and LiPuma JJ (2002) Comparative assessment of genotyping methods for epidemiologic study of Burkholderia cepacia Genomovar III. J Clin Microbiol 40:3300-3307.

Cruz LM, Souza EM, Weber OB, Baldani JI, Döbereiner J and Pedrosa FO (2001) 16S ribosomal DNA characterization of nitrogen-fixing bacteria isolated from banana (Musa spp.) and pineapple (Ananas comosus (L.) Merril). Appl Environ Microbiol 67:2375-2379.

Dice LR (1945) Measures of the amount of ecologic association between species. Ecology 26:297-302.
Döbereiner J and Pedrosa FO (1987) The genus Azospirillum. In: Nitrogen-fixing bacteria in non-leguminous crop plants. Madison: Science Tech. Publishers, 155 pp.

Döbereiner J (1991) The genera Azospirillum and Herbaspirillum. In: Ballows A, Triiper HG, Dowrkin M, Harder W (eds) The Prokaryotes. Berlin: Springer-Verlag, pp 2236-2253.

Döbereiner J, Baldani VLD and Reis VM (1995) Endophytic occurrence of diazotrophic bacteria in non-leguminous crops. In: Fendrik I, del Gallo M, Vanderleyden J, de Zamaroczy M (eds) Azospirillum VI and related microorganisms. Berlin, Heidelberg: Springer-Verlag, pp 15-30.

Gillis M, Döbereiner J, Pot B, Goor M, Falsen E, Hoste B, Reinhold B and Kersters K (1990) Taxonomic relationships between [Pseudomonas] rubrisubalbicans, some clinical isolates (EF GROUP 1), Herbaspirillum seropedicae and [Aquaspirillum] authrotrophicum. In: Polsinelli M, Materassi R, Vincenzini M (eds) Nitrogen Fixation. Dordrecht: kluver Acad. Publish. pp 293-294.

Gutell RR, Larsen N and Woese CR (1994) Lessons from an evolving rRNA: $16 \mathrm{~S}$ and 23S rRNA structures from a comparative perspective. Microbiol Rev 58:10-26.

Hall TA (1999) BioEdit: a user-friendly biological sequence alignment editor and analysis program for Windows 95/98/NT. Nucleic Acids Symp Ser 41:95-98.

Huang X (1992) A contig assembly program based on sensitive detection of fragment overlaps. Genomics 14:18-25.

Kirchhof G, Eckert B, Stoffels M, Baldani JI, Reis VM and Hartmann A (2001) Herbaspirillum frisingense sp. nov., a new nitrogen-fixing bacterial species that occurs in C4-fibre plants. Int J Syst Evol Microbiol 1:157-168.

Klassen G, Pedrosa FO, Souza EM, Funayama S and Rigo LU (1997) Effect of nitrogen compounds on nitrogenase activity in Herbaspirillum seropedicae SMR1. Can J Microbiol 43:887-891.

Kumar S, Tamura K, Jakobsen IB and Nei M (2001) Mega 2: molecular evolutionary genetic analysis software. Bioinformatics 17:1244-1245.

Lasker BA (2002) Evaluation of performance of four genotypic methods for studying the genetic epidemiology of Aspergillus fumigatus isolates. J Clin Microbiol 40:28862892.

Luz SP, Rodriguez-Valera F, Lan R and Reeves PR (1998) Variation of the ribosomal operon $16 \mathrm{~S}-23 \mathrm{~S}$ gene spacer region in representatives of Salmonella enterica subspecies. J Bacteriol 180:2144-2151.

McArthur JV, Kovacic DA and Smith MH (1988) Genetic diversity in natural populations of a soil bacterium across a landscape gradient. Proc Natl Acad Sci 85:9621-9624.

Olivares FL, James EK, Reis VM, Baldani VLD, Baldani JI and Döbereiner J (1993) Colonização do tecido vascular por Herbaspirillum spp. em sorgo e cana-de-açúcar. Fitopat Bras 18:313.

Olivares FL, James EK, Baldani JI and Döbereiner J (1996) Infection of mottled stripe disease-susceptible and resistant sugar cane varieties by the endophytic diazotroph Herbaspirillum. New Phytol 135:723-737.

Penner GA, Bush A, Wise R, Kim W, Domier L, Kasha K, Laroche A, Scoles G, Molnar SJ and Fedak G (1993) Reproducibility of random amplified polymorphic DNA (RAPD) analysis among laboratories. PCR Methods Appl 2:341-345. 
Sokal RR and Michener CD (1958) A statistical method for evaluating systematic relationships. Univ Kans Sci Bull 38:1409-1438.

van den Braak N, Power E, Anthony R, Endtz HP, Verbrugh HA and van Belkum A (2000) Random amplification of polymorphic DNA versus pulsed field gel electrophoresis of SmaI DNA macrorestriction fragments for typing strains of vancomycin-resistant enterococci. FEMS Microbiol Lett 192:45-52.

Wang D, Wayne MMY, Taricani M, Buckingam K and Sandham HJ (1993) Artifactual variation in randomly amplified polymorphic DNA banding patterns. Biotechniques 14:214-218.

Woese CR (1987) Bacterial evolution. Microbiol Rev 512:22171.

Young JPW, Downer HL and Eardly BD (1991) Phylogeny of the phototrophic Rhizobium strains BTAil by polymerase chain reaction-based sequencing of a $16 \mathrm{~S}$ rRNA gene segment. J Bacteriol 173:2271-2277.

Zhang GW, Kotiw M and Daggard G (2002) A RAPD-PCR genotyping assay which correlates with serotypes of group B streptococci. Lett Appl Microbiol 35:247 250.

Editor: Darcy Fontoura de Almeida 